\title{
Physiological Role of Antioxidants in Improving Growth and Productivity of Sunflower under Different Sources of Nitrogen Fertilizers
}

\author{
Rania F. El Mantawy ${ }^{\#}$ \\ Crop Physiology Research Department, Field Crops Research Institute, Agricultural \\ Research Center,Egypt.
}

\begin{abstract}
TWO FIELD trials were conducted at Sakha Agricultural Research Station $31^{\circ} 07^{\|} \mathrm{N}$ $A$ and $30^{\circ}$ 57", Kafr El-Sheikh, Egypt to determine the effect of foliar application of some antioxidants and different sources of nitrogen fertilizers on growth, yield and its components of sunflower (Helianthus annuus L.) cultivar Sakha 53 during the two successive summer seasons 2014 and 2015. A split plot design with four replications was used in the present work. The main plots were randomly assigned to three different sources of nitrogen (urea, ammonium nitrate and ammonium sulfate).Sub plots were randomly devoted to antioxidants treatments i.e. spray with water as control, spray with 150 and $300 \mathrm{mg} \mathrm{L}^{-1}$ of ascorbic acid and spray with 250 and $500 \mathrm{mg} \mathrm{L}^{-1}$ of citric acid. The results revealed that, different nitrogen sources significantly affected growth, yield, yield components and yield quality of sunflower plants during the two seasons. Remarkable results noticed at nitrogen sources ammonium sulfate followed by ammonium nitrate and urea. Also, applications of the antioxidants (ascorbic acid and citric acid) were very effective in improving growth characters namely plant height, stem diameter, head diameter ,leaf area plant ${ }^{-1}$,seed yield $\mathrm{kg} \mathrm{fad}^{-1}$, seed oil \%,seed protein $\%$ and plant pigments in relative to the control treatment.
\end{abstract}

Keywords: Nitrogen sources, Antioxidants, Growth, Productivity, Sunflower.

\section{Introduction}

Sunflower (Helianthus annuusL.) is an important oil seed crop which ranks fourth after palm oil, soybean and canola along with other oil seed crops like (peanut and cotton seeds) which contributes as edible oils in the world (FAS-USDA, 2017). Sunflower seeds contain a high amount of oil (40 to $45 \%$ ) which is an important source of the mono and polyunsaturated fatty acid (oleic, linoleic and linolenic acids) of potential health benefits (Lopez et al..,2000; Leon et al., 2003 and Monotti, 2004).

Fertilization needs to be used in moderate levels in order to avoid a negative ecological effects of agricultural production systems. Excessive application of fertilizers also affects the farmer's economy (Zubillaga et al., 2002). Nitrogen $(\mathrm{N})$ element is one of the most important nutrients that improve vegetative growth as well as yield and quality of all crops. (Nasim et al., 2012).

Recently, a great efforts have been made by
Egyptian scientists to use natural and safety substances in order to increase plant growth and productivity. In this concern, antioxidants have great effects on growth, yield and yield quality of many plant species (Al-Qubaie, 2012). One of the most important antioxidants is citric acid which is presented in tricarboxilic acid cycle or malic acid conversion to citric acid. Nofal et al. (1990) found that, growth of cotton, corn, bean, pea and sunflower increased by organic acids external treatment especially succinic, citric and malic acids. Also, citric acid is considered as one of nonenzymatic antioxidants caused an increment in growth characters of sunflower plants, compared with untreated plants (Abd El-Al, 2009).

Additionally, ascorbic acid (vitamin C) is a product of D-glucose metabolism that regulates plant growth and development (El-Kobisy et al., 2005). Ascorbic acid also plays an important role in plant growth such as, regulation of cell division, photosynthesis, flowering, cell wall expansion and other developmental processes (Davey et al.,

\#Corresponding author email: raniafarouk711@gmail.com

DOI :10.21608/agro.2017.761.1060

C2017 National Information and Documentation Center (NIDOC) 
2000 and Barth et al., 2006). With regard to sunflower crop, Gamal El-Din (2005) found that ascorbic acid application increased plant height, stem and head diameters and seed yield/ fad. Also, ascorbic acid act as an important cofactor in biosynthesis of many plant hormones such as gibberellic and abscisic acids (De Tullio \& Arrigoni, 2003).

The main objective of this research is to determine the effect of different sources of nitrogen fertilizers with foliar application of ascorbic and citric acids as antioxidants in order to improve growth, productivity and quality of sunflower plants .

\section{Materials and Methods}

The present study was carried out at the Experimental Farm of Sakha Agricultural Research Station, $31^{\circ} 07^{\backslash} \mathrm{N}$ and $30^{\circ} 57^{\backslash} \mathrm{Kafr}$ ElSheikh, ARC Egypt during the two successive summer seasons 2014 and 2015 to study the effect of different sources of nitrogen fertilizers and foliar spraying of some antioxidants on growth, yield and its components of sunflower (Helianthus annuus L.) cultivar Sakha 53. Soil samples were randomly taken from the experimental site at depth of 0 to $30 \mathrm{~cm}$ from soil surface and were analyzed for both physical and chemical characteristics according to Piper (1950). The seeds were sown on $26^{\text {th }}$ of July in the two seasons using split plot design with four replicates. The main plots were devoted to three different sources of nitrogen i.e., urea $(46.5 \% \mathrm{~N})$, ammonium nitrate $(33 \% \mathrm{~N})$ and ammonium sulfate $(20.5 \% \mathrm{~N})$ at the rate of $30 \mathrm{~kg} \mathrm{~N} /$ fad. While, sub plots were randomly assigned to antioxidants treatments i.e., spray with water as control, spray with 150,300 $\mathrm{mg} \mathrm{L} \mathrm{L}^{-1}$ of ascorbic acid and $250,500 \mathrm{mg} \mathrm{L}^{-1}$ of citric acid were sprayed twice at 30 and 40 days after sowing. The plot area was $12 \mathrm{~m}^{2}$ (3 $\mathrm{m}$ width and $4 \mathrm{~m}$ length), each plot contains 5 rows and seeds were sown by hand and the distance between hills were $20 \mathrm{~cm}$. Two rows were used for growth analysis data and anther three rows were left for determining seed yield and its components. The plants were thinned to one plant per hill after 21 days from sowing. Other cultural practices for growing sunflower were conducted as recommended. According to soil analysis and sunflower fertilizer requirements, Phosphorus was appliedat a rate of $100 \mathrm{~kg} \mathrm{P} / \mathrm{fad}$. using calcium superphosphate $\left(15.5 \% \mathrm{P}_{2} \mathrm{O}_{5}\right)$.

TABLE 1. Physical and chemical analysis of the experimental site during the two seasons of study(2014 and 2015).

\begin{tabular}{llll}
\hline \multicolumn{1}{c}{ Determination } & $1^{s t}$ & Season & $2^{\text {nd }}$ \\
\hline Physical analysis & & &
\end{tabular}

Sand \%

41.00

40.25

Silt \%

Clay \%

Soil texture class

Clay

Clay

Chemical analysis

Soil reaction $\left({ }_{\mathrm{P}} \mathrm{H}\right)$

Organic matter(\%)

Available $\mathrm{N} \mathrm{mg} \mathrm{L}^{-1}$

18.00

18.22

Available $\mathrm{P}$ mg L ${ }^{-1}$

15.00

15.31 


\section{Studied characteristics}

Representative plant samples were taken randomly from the second and third row of each plot at the age of 35, 50 and 65 days after sowing to estimate the following traits:

1-Photosynthetic pigment content in leaves

The total chlorophyll pigments were determined by reading the absorbance on spectrophotometer at 664 and $647 \mathrm{~nm}$. Leaf samples were homogenized in N-Ndimethyl formamid and the concentration of photosynthetic pigments were calculated according to the equation mentioned by Moran (1982):

Chl. $\mathrm{A}=12.7$ (O.D)6642.79-(O.D)647 $=\mathrm{mgL}^{-1}$ Chl. B $=20.7$ (O.D)6474.62-(O.D)664 $=\mathrm{mg} \mathrm{L}^{-1}$

\section{2- Leaf area plant ${ }^{-1}$ in $\mathrm{dm}^{2}$}

The disc method was used according to Johanson (1967). The cross sectional area of the punch used was (1.5) $\mathrm{cm}^{2}$ and 100 discs were taken for all samples. Leaf blades were only used in calculating leaf area by using the areaweight relationship.

\section{Yield and its components}

At maturity five guarded plants were taken randomly from inner ridges and characters were recorded:

1- Plant height $(\mathrm{cm})$ was recorded at maturity, stem diameter $(\mathrm{cm})$ and head diameter $(\mathrm{cm})$ were recorded from 5 plants which selected randomly and then averaged.

2- To calculate the average 100-seed weight(g), five samples were randomly taken from each plot and mean of weight was recorded.

3- Seed yield $\mathrm{kg}$ fad $^{-1}$ heads of bagged plants from inner ridges of each plot were harvested and left two weeks until fully air dried and seed weight was used to estimate seed yield $\mathrm{kg} \mathrm{fad}^{-1}$.

4- Seed oil (\%) was determined according to A.O.A.C. (1995) using soxhlet apparatus using petroleum ether as a solvent.

5- Seed protein (\%) was determined according to A.O.A.C. (1995) and calculated by multiplying the $\mathrm{N}$ by the converting factor 6.25 (Hymowitz et al., 1972).

The obtained data of the different treatments were statistically analyzed and comparison among means was performed by computer programming methods (statgraphics, v. 4.2 software) as described by Snedecor \& Cochran (1982).

\section{Results and Discussions}

\section{Effect on Chlorophyll content}

Different sources of nitrogen fertilizers have an important effect on accumulation of chlorophyll pigments in plants. The results summarized in Tables 2, 3 and 4 revealed that, nitrogen application significantly affected chlorophyll content at different growth stages during the two studied seasons. The greatest values of chlorophyll content (chl. a , chl. b \& chl. $\mathrm{a}+\mathrm{chl} . \mathrm{b}$ ) were recorded with application of ammonium sulfate fertilizers. These results may be due to the role of sulfur element in synthesis of proteins, oils, vitamins, and flavoured compounds in plants. Also, it is a constituent of three amino acids Methionine (21\% S), Cysteine $(26 \%$ S) and Cystine $(27 \%$ S), which are the building blocks of protein. This results are in harmony with Patra et al.(2013).

It is evident from the data in Tables 2, 3 and 4 that spraying the plants twice with antioxidants significantly resulted in enhancing plant pigments in fresh leaves namely chlorophylls a \& b and total chlorophylls in comparison to the control treatment. Using ascorbic acid at $300 \mathrm{mg} \mathrm{L}^{-1}$ effectively maximized chlorophyll content in leaves in comparison to the control during the two studied seasons. These results may be due to the positive effects of ascorbate in photosynthesis, growth, stress resistance, development and oxidative-stress signaling. These results are in line with those reported by Abd El- Hakim (2006) and Abd El- Naem \& Abd El- Hakim (2009) on different legumes.

\section{Effects on leaf area:}

The data in Table 5 clearly showed that, the nitrogen sources affected significantly leaf area at different growth stages during the two growing seasons.Fertilizing plants with ammonium sulfate recorded the higher leaf area plant $^{-1}$ at the three growth stages as compared with other nitrogen sources. These results may be due to ammonium sulfate containing sulfur element which is a constituent of succinyl Co-A which is involved in chlorophyll in leaves and their activation at cellular level accelerate photosynthesis which ultimately promote vegetative growth and leaf area. Similar results were reported by Ralsool et al. (2013). 
TABLE 2. Effects of different sources of nitrogen fertilizers and spraying of someantioxidants on chlorophyll content at 35 days after sowing during the two growing seasons.

\begin{tabular}{lcccccc}
\hline \multirow{2}{*}{ Treatment } & \multicolumn{2}{c}{ Chl.a $\left(\mathbf{m g} / \mathbf{d m}^{2}\right)$} & \multicolumn{2}{c}{ Chl.b $\left(\mathbf{m g} / \mathbf{d m}^{2}\right)$} & \multicolumn{2}{c}{ Total Chl. $\left(\mathbf{m g} / \mathbf{d m}^{2}\right)$} \\
& $\mathbf{2 0 1 4}$ & $\mathbf{2 0 1 5}$ & $\mathbf{2 0 1 4}$ & $\mathbf{2 0 1 5}$ & $\mathbf{2 0 1 4}$ & $\mathbf{2 0 1 5}$ \\
\hline \multicolumn{7}{c}{ Nitrogen fertilizers sources } \\
\hline Urea & $1.734 \mathrm{c}$ & $2.073 \mathrm{c}$ & $1.250 \mathrm{c}$ & $1.555 \mathrm{c}$ & $3.298 \mathrm{c}$ & $3.629 \mathrm{c}$ \\
Ammonium nitrate & $1.889 \mathrm{~b}$ & $2.267 \mathrm{~b}$ & $1.360 \mathrm{~b}$ & $1.701 \mathrm{~b}$ & $3.257 \mathrm{~b}$ & $3.968 \mathrm{~b}$ \\
Ammonium sulfate & $2.019 \mathrm{a}$ & $2.422 \mathrm{a}$ & $1.460 \mathrm{a}$ & $1.817 \mathrm{a}$ & $3.483 \mathrm{a}$ & $4.240 \mathrm{a}$ \\
F -test & $*$ & $* *$ & $* *$ & $*$ & $* *$ & $* *$ \\
LSD & 0.040 & 0.022 & 0.034 & 0.036 & 0.072 & 0.085 \\
\hline & \multicolumn{7}{c}{ Antioxidants concentrations } & & \\
\hline Control (untreated plants) & $1.593 \mathrm{e}$ & $1.912 \mathrm{e}$ & $1.154 \mathrm{e}$ & $1.434 \mathrm{e}$ & $2.747 \mathrm{e}$ & $3.346 \mathrm{e}$ \\
Ascorbic at $150 \mathrm{mg} \mathrm{L}^{-1}$ & $1.876 \mathrm{c}$ & $2.252 \mathrm{c}$ & $1.367 \mathrm{c}$ & $1.689 \mathrm{c}$ & $3.243 \mathrm{c}$ & $3.941 \mathrm{c}$ \\
Ascorbic acid at $300 \mathrm{mg} \mathrm{L}^{-1}$ & $2.195 \mathrm{a}$ & $2.634 \mathrm{a}$ & $1.592 \mathrm{a}$ & $1.976 \mathrm{a}$ & $3.788 \mathrm{a}$ & $4.611 \mathrm{a}$ \\
Citric acid at $250 \mathrm{mg} \mathrm{L}^{-1}$ & $1.680 \mathrm{~d}$ & $2.017 \mathrm{~d}$ & $1.215 \mathrm{~d}$ & $1.512 \mathrm{~d}$ & $2.895 \mathrm{~d}$ & $3.529 \mathrm{~d}$ \\
Citric acid at $500 \mathrm{mg} \mathrm{L}^{-1}$ & $2.048 \mathrm{~b}$ & $2.458 \mathrm{~b}$ & $1.486 \mathrm{~b}$ & $1.843 \mathrm{~b}$ & $3.535 \mathrm{~b}$ & $4.302 \mathrm{~b}$ \\
F- test & $* *$ & $*$ & $* *$ & $*$ & $* *$ & $* *$ \\
LSD & 0.021 & 0.025 & 0.018 & 0.019 & 0.038 & 0.060
\end{tabular}

*** significant at $5 \%$ level of probability, respectively. Mean values designed by the same letter in each column are not significant according to Duncan's Multiple Range Test.

TABLE 3. Effects of different sources of nitrogen fertilizers and spraying of some antioxidants on chlorophyll content at 50 days after sowing during the two growing seasons.

\begin{tabular}{|c|c|c|c|c|c|c|}
\hline \multirow{2}{*}{ Treatment } & \multicolumn{2}{|c|}{ Chl.a (mg/dm²) } & \multicolumn{2}{|c|}{ Chl.b (mg/dm²) } & \multicolumn{2}{|c|}{ Total Chl. (mg/dm²) } \\
\hline & 2014 & 2015 & 2014 & 2015 & 2014 & 2015 \\
\hline \multicolumn{7}{|c|}{ Nitrogen fertilizers sources } \\
\hline Urea & $2.154 \mathrm{c}$ & $2.177 \mathrm{c}$ & $1.523 \mathrm{c}$ & $1.633 \mathrm{c}$ & $3.678 \mathrm{c}$ & $3.811 \mathrm{c}$ \\
\hline Ammonium nitrate & $2.345 \mathrm{~b}$ & $2.381 \mathrm{~b}$ & $1.660 \mathrm{~b}$ & $1.786 \mathrm{~b}$ & $4.006 \mathrm{~b}$ & $4.167 \mathrm{~b}$ \\
\hline Ammonium sulfate & $2.509 \mathrm{a}$ & $2.544 \mathrm{a}$ & $1.776 \mathrm{a}$ & $1.908 \mathrm{a}$ & $4.285 \mathrm{a}$ & $4.452 \mathrm{a}$ \\
\hline F- test & $*$ & $* *$ & $* *$ & $*$ & $* *$ & $* *$ \\
\hline LSD & 0.079 & 0.051 & 0.036 & 0.038 & 0.156 & 0.090 \\
\hline \multicolumn{7}{|c|}{ Antioxidants concentrations } \\
\hline Control (untreated plants) & $1.978 \mathrm{e}$ & $2.008 \mathrm{e}$ & $1.400 \mathrm{e}$ & $1.506 \mathrm{e}$ & $3.379 \mathrm{e}$ & $3.504 \mathrm{e}$ \\
\hline Ascorbic at $150 \mathrm{mg} \mathrm{L}^{-1}$ & $2.342 \mathrm{c}$ & $2.581 \mathrm{c}$ & $1.656 \mathrm{c}$ & $1.773 \mathrm{c}$ & $3.998 \mathrm{c}$ & $4.138 \mathrm{c}$ \\
\hline Ascorbic acid at $300 \mathrm{mg} \mathrm{L}^{-1}$ & $2.730 \mathrm{a}$ & $2.766 \mathrm{a}$ & $1.932 \mathrm{a}$ & $2.075 \mathrm{a}$ & $4.662 \mathrm{a}$ & $4.841 \mathrm{a}$ \\
\hline Citric acid at $250 \mathrm{mg} \mathrm{L}^{-1}$ & $2.083 \mathrm{~d}$ & $2.118 \mathrm{~d}$ & $1.475 \mathrm{~d}$ & $1.588 \mathrm{~d}$ & $3.559 \mathrm{~d}$ & $3.706 \mathrm{~d}$ \\
\hline Citric acid at $500 \mathrm{mg} \mathrm{L}^{-1}$ & $2.547 \mathrm{~b}$ & $2.364 \mathrm{~b}$ & $1.803 b$ & $1.936 \mathrm{~b}$ & $4.350 \mathrm{~b}$ & $4.517 b$ \\
\hline F- test & $* *$ & $*$ & $* *$ & $* *$ & $*$ & $* *$ \\
\hline LSD & 0.035 & 0.036 & 0.036 & 0.020 & 0.070 & 0.047 \\
\hline
\end{tabular}


TABLE 4. Effects of different sources of nitrogen fertilizer and spraying of some antioxidants on chlorophyll content at 65 days after sowing during the two growing seasons.

\begin{tabular}{lcccccc}
\hline \multirow{2}{*}{ Treatment } & \multicolumn{2}{c}{ Chl.a $\left(\mathbf{m g} / \mathbf{d m}^{2}\right)$} & \multicolumn{2}{c}{ Chl.b (mg/dm $\left.{ }^{2}\right)$} & \multicolumn{2}{c}{ Total Chl. $\left(\mathbf{m g} / \mathbf{d m}^{2}\right)$} \\
& $\mathbf{2 0 1 4}$ & $\mathbf{2 0 1 5}$ & $\mathbf{2 0 1 4}$ & $\mathbf{2 0 1 5}$ & $\mathbf{2 0 1 4}$ & $\mathbf{2 0 1 5}$ \\
\hline \multicolumn{7}{c}{ Nitrogen fertilizers sources } \\
\hline Urea & $2.346 \mathrm{c}$ & $2.286 \mathrm{c}$ & $1.936 \mathrm{c}$ & $1.974 \mathrm{c}$ & $4.282 \mathrm{c}$ & $4.261 \mathrm{c}$ \\
Ammonium nitrate & $2.557 \mathrm{~b}$ & $2.500 \mathrm{~b}$ & $2.109 \mathrm{~b}$ & $2.158 \mathrm{~b}$ & $4.667 \mathrm{~b}$ & $4.659 \mathrm{~b}$ \\
Ammonium sulfate & $2.735 \mathrm{a}$ & $2.671 \mathrm{a}$ & $2.256 \mathrm{a}$ & $2.306 \mathrm{a}$ & $4.992 \mathrm{a}$ & $4.977 \mathrm{a}$ \\
F- test & $* *$ & $* *$ & $* *$ & $* *$ & $* *$ & $* *$ \\
LSD & 0.119 & 0.054 & 0.098 & 0.046 & 0.217 & 0.101 \\
\hline & Antioxidants concentrations & & & \\
\hline Control (untreated plants) & $2.156 \mathrm{e}$ & $2.108 \mathrm{e}$ & $1.779 \mathrm{e}$ & $1.820 \mathrm{e}$ & $3.936 \mathrm{e}$ & $3.928 \mathrm{e}$ \\
Ascorbic at $150 \mathrm{mg} \mathrm{L}^{-1}$ & $2.551 \mathrm{c}$ & $2.483 \mathrm{c}$ & $2.104 \mathrm{c}$ & $2.143 \mathrm{c}$ & $4.656 \mathrm{c}$ & $4.627 \mathrm{c}$ \\
Ascorbic acid at $300 \mathrm{mg} \mathrm{L}^{-1}$ & $2.975 \mathrm{a}$ & $2.904 \mathrm{a}$ & $2.454 \mathrm{a}$ & $2.508 \mathrm{a}$ & $5.430 \mathrm{a}$ & $5.413 \mathrm{a}$ \\
Citric acid at $250 \mathrm{mg} \mathrm{L}^{-1}$ & $2.272 \mathrm{~d}$ & $2.224 \mathrm{~d}$ & $1.874 \mathrm{~d}$ & $1.920 \mathrm{~d}$ & $4.146 \mathrm{~d}$ & $4.144 \mathrm{~d}$ \\
Citric acid at $500 \mathrm{mg} \mathrm{L}^{-1}$ & $2.776 \mathrm{~b}$ & $2.710 \mathrm{~b}$ & $2.290 \mathrm{~b}$ & $2.340 \mathrm{~b}$ & $5.067 \mathrm{~b}$ & $5.050 \mathrm{~b}$ \\
F- test & $* *$ & $* *$ & $* *$ & $* *$ & $* *$ & $* *$ \\
LSD & 0.055 & 0.028 & 0.045 & 0.024 & 0.010 & 0.053 \\
\hline
\end{tabular}

*** significant at 5\% level of probability, respectively. Mean values designed by the same letter in each column are not significant according to Duncan's Multiple Range Test.

TABLE 5. Effects of different sources of nitrogen fertilizers and spraying of some antioxidants on leaf area plant ${ }^{-1}$ at different growth stages during the two growing seasons.

\begin{tabular}{|c|c|c|c|c|c|c|}
\hline \multirow{3}{*}{ Treatment } & \multicolumn{6}{|c|}{ Leaf area plant ${ }^{-1}\left(\mathrm{dm}^{2}\right)$} \\
\hline & \multicolumn{2}{|c|}{35 days } & \multicolumn{2}{|c|}{50 days } & \multicolumn{2}{|c|}{65 days } \\
\hline & 2014 & 2015 & 2014 & 2015 & 2014 & 2015 \\
\hline \multicolumn{7}{|c|}{ Nitrogen fertilizers sources } \\
\hline Urea & $16.47 \mathrm{c}$ & $15.72 \mathrm{c}$ & $29.40 \mathrm{c}$ & $30.41 \mathrm{c}$ & $55.96 \mathrm{c}$ & $56.82 \mathrm{c}$ \\
\hline Ammonium nitrate & $16.06 b$ & $16.67 \mathrm{~b}$ & $30.05 \mathrm{~b}$ & $31.01 \mathrm{~b}$ & $57.08 \mathrm{~b}$ & $57.85 \mathrm{~b}$ \\
\hline Ammonium sulfate & $15.07 \mathrm{a}$ & $16.98 \mathrm{a}$ & $31.51 \mathrm{a}$ & $32.21 \mathrm{a}$ & $58.01 \mathrm{a}$ & $58.77 \mathrm{a}$ \\
\hline F- test & $*$ & $*$ & $* *$ & $* *$ & $* *$ & $* *$ \\
\hline LSD & 0.482 & 0.591 & 0.563 & 0.500 & 0.371 & 0.345 \\
\hline \multicolumn{7}{|c|}{ Antioxidants concentrations } \\
\hline Control (untreated plants) & $12.60 \mathrm{e}$ & $13.29 \mathrm{e}$ & $22.49 \mathrm{e}$ & $23.36 \mathrm{e}$ & $54.76 \mathrm{e}$ & $55.63 \mathrm{e}$ \\
\hline Ascorbic at $150 \mathrm{mg} \mathrm{L}^{-1}$ & $15.98 \mathrm{c}$ & $16.64 \mathrm{c}$ & $31.67 \mathrm{c}$ & $32.58 \mathrm{c}$ & $56.47 \mathrm{c}$ & $57.26 \mathrm{c}$ \\
\hline Ascorbic acid at $300 \mathrm{mg} \mathrm{L}^{-1}$ & $18.08 \mathrm{a}$ & $18.61 \mathrm{a}$ & $33.88 \mathrm{a}$ & $34.87 \mathrm{a}$ & $59.36 \mathrm{a}$ & $60.16 \mathrm{a}$ \\
\hline Citric acid at $250 \mathrm{mg} \mathrm{L}^{-1}$ & $15.41 \mathrm{~d}$ & $15.96 \mathrm{~d}$ & $30.62 \mathrm{~d}$ & $31.48 \mathrm{~d}$ & $55.90 \mathrm{~s} \mathrm{~d}$ & $56.76 \mathrm{~d}$ \\
\hline Citric acid at $500 \mathrm{mg} \mathrm{L}^{-1}$ & $17.24 \mathrm{~b}$ & $17.78 \mathrm{~b}$ & $32.94 \mathrm{~b}$ & $33.77 \mathrm{~b}$ & $58.60 \mathrm{~b}$ & $59.29 \mathrm{~b}$ \\
\hline F- test & $* *$ & $* *$ & $* *$ & $* *$ & $* *$ & $* *$ \\
\hline LSD & 0.294 & 0.370 & 0.385 & 0.428 & 0.403 & 0.638 \\
\hline
\end{tabular}

*,** significant at $5 \%$ level of probability, respectively. Mean values designed by the same letter in each column are not significant according to Duncan's Multiple Range Test. 
Additionally, exogenous application of antioxidants caused significant increase in leaf area at the different growth stages during the two growing seasons. The treatment of $300 \mathrm{mg}$ $\mathrm{L}^{-1}$ of ascorbic acid recoded the highest leaf area plant $^{-1}$ in comparison to the other treatment. These results may be due to both ascorbic and citric acidsare involved in the regulation of many critical biological processes such as and cell elongation (Noctor et al., 1998); many other important enzymatic and non-enzymatic reactions (Smirnoff, 2000); as well as in regulating plant growth and development, since they plays an important role as plant growth regulator which cause important effectson physiological processes in plants as cell elongation, cell division and cell differentiation which in turn reflected on plant leaf area (Athar et al., 2008).

\section{Effect on plant height}

The obtained results in Table 6 revealed that, plant height was significantly affected by different nitrogen sources in both seasons. The application of ammonium sulfate produced significantly the tallest plants $(177.3 \mathrm{~cm})$ in the first season and $(180.27 \mathrm{~cm})$ in the second season respectively, followed by treatment with ammonium nitrate which produced plant height of (176.04 and 178.53 $\mathrm{cm}$ ) in both seasons, respectively. Shortest plant height was obtained with urea (174.77 and 176.62 $\mathrm{cm})$.The increase in plant height with different nitrogen sources can be attributed to the fact that nitrogen as ammonium sulfate promotes plant growth, increases the number and length of the internodes which resulted in progressive increase in plant height. This resultsare in agreement with the finding of Abdel Gader (2007) in corn.

It is worthy to mention that significant differences in plant height were obtained with spraying antioxidants treatments.Plant height significantly increased with using the antioxidants rather than non- application (control). The tallest plants were obtained with ascorbic at $300 \mathrm{mg} \mathrm{L}^{-1}$ during the two growing seasons.

TABLE 6. Effects of different sources of nitrogen fertilizers and spraying of some antioxidants onplant height, stem diameter andhead diameter during the two growing seasons.

\begin{tabular}{lcccccc}
\hline \multirow{2}{*}{ Treatment } & \multicolumn{7}{c}{ Plant height (cm) } & \multicolumn{2}{c}{ Stem diameter (cm) } & \multicolumn{2}{c}{ Head diameter (cm) } \\
\cline { 2 - 8 } & $\mathbf{2 0 1 4}$ & $\mathbf{2 0 1 5}$ & $\mathbf{2 0 1 4}$ & $\mathbf{2 0 1 5}$ & $\mathbf{2 0 1 4}$ & $\mathbf{2 0 1 5}$ \\
\hline \multicolumn{6}{c}{ Nitrogen fertilizers sources } \\
Urea & $174.77 \mathrm{c}$ & $176.62 \mathrm{c}$ & $2.37 \mathrm{c}$ & $2.52 \mathrm{~b}$ & $14.81 \mathrm{c}$ & $15.18 \mathrm{~b}$ \\
Ammonium nitrate & $176.04 \mathrm{~b}$ & $178.53 \mathrm{~b}$ & $2.47 \mathrm{~b}$ & $2.66 \mathrm{a}$ & $15.19 \mathrm{~b}$ & $15.38 \mathrm{a}$ \\
Ammonium sulfate & $177.3 \mathrm{a}$ & $180.27 \mathrm{a}$ & $2.62 \mathrm{a}$ & $2.74 \mathrm{a}$ & $15.39 \mathrm{a}$ & $15.61 \mathrm{a}$ \\
F- test & $* *$ & $* *$ & $* *$ & $*$ & $* *$ & $*$ \\
LSD & 0.989 & 1.582 & 0.037 & 0.096 & 0.175 & 0.234 \\
\hline & Antioxidants concentrations & & & \\
\hline Control (untreated plants) & $173.47 \mathrm{e}$ & $175.56 \mathrm{e}$ & $2.28 \mathrm{e}$ & $2.44 \mathrm{~d}$ & $14.70 \mathrm{e}$ & $14.91 \mathrm{~d}$ \\
Ascorbic at $150 \mathrm{mg} \mathrm{L}^{-1}$ & $175.29 \mathrm{c}$ & $178.14 \mathrm{c}$ & $2.48 \mathrm{c}$ & $2.54 \mathrm{c}$ & $15.17 \mathrm{c}$ & $15.39 \mathrm{~b}$ \\
Ascorbic acid at $300 \mathrm{mg} \mathrm{L}^{-1}$ & $179.61 \mathrm{a}$ & $182.29 \mathrm{a}$ & $2.74 \mathrm{a}$ & $2.93 \mathrm{a}$ & $15.63 \mathrm{a}$ & $15.74 \mathrm{a}$ \\
Citric acid at 250 $\mathrm{mg} \mathrm{L}^{-1}$ & $174.19 \mathrm{~d}$ & $176.66 \mathrm{~d}$ & $2.38 \mathrm{~d}$ & $2.51 \mathrm{c}$ & $14.82 \mathrm{~d}$ & $15.09 \mathrm{c}$ \\
Citric acid at $500 \mathrm{mg} \mathrm{L}^{-1}$ & $177.62 \mathrm{~b}$ & $179.70 \mathrm{~b}$ & $2.57 \mathrm{~b}$ & $2.77 \mathrm{~b}$ & $15.33 \mathrm{~b}$ & $15.54 \mathrm{~b}$ \\
F -test & $* *$ & $* *$ & $* *$ & $* *$ & $* *$ & $*$ \\
LSD & 0.717 & 1.152 & 0.079 & 0.065 & 0.118 & 0.160
\end{tabular}

*** significant at $5 \%$ level of probability, respectively. Mean values designed by the same letter in each column are not significant according to Duncan's Multiple Range Test. 


\section{Effect on stem and head diameters}

Data in Table 6 showed that, stem and head diameters were significantly increased in all treated plants during the two seasons. The thickest stem and biggest head diameters were noticed for ammonium sulfate followed by ammonium nitrate and urea. This increase may be due to application of nitrogen which promotes plants growth as well as cell division and elongation. Application of nitrogen fertilizers in the form of ammonium sulfate recorded the highest values of both stem and head diameters, this increase can be ascribed to the presence of sulfur which promote plant growth as reported by Elmar (2001).

It is revealed from the data in Table 6 that applications of the two antioxidants caused a significant promotion on both stem and head diameters . In comparison to the control, applications of ascorbic acid at $300 \mathrm{mg} \mathrm{L}^{-1}$ is significantly effective in improving growth characters (stem and head diameter) during the two seasons. These results are in harmony with Al- Qubaie (2012).

Effect on yield and its components

On the light of the present data in Table 7 different sources of nitrogen fertilizers have significant effect on 100 seed weight and seed yield. Application of ammonium sulfate recorded the greatest values of seed yield during the two growing seasons. Malik et al. (1996) reported that, to compare between effect of urea and ammonium sulfate on 1000 seed weight of Highsun-33cv.,all treatments with ammonium sulfate produced higher weight compared to the other treatment. Also, Toosi \& Azizi (2014) recorded that Ammonium sulfate producedt he highest seed yield.

Moreover, the positive effect of ascorbic acid on growth parameters may be due to that, ascorbic acid has a stimulatory effect of many physiological processes, such as respiration activities, cell division and many enzymes activities as reported by Zewail (2007), Bakry et al. (2012) and Youssef et al . (2015). It also play an important role in regulation of photosynthetic carbon reduction (Helsper et al., 1982). The positive effect of ascorbic acid on growth parameter are in harmony with those obtained by Hanna et al. (2001), Irfan et al. (2006), Hassanein et al. (2009), Hussein et al. (2011), Bakry et al. (2012), Nassar (2013) and Tarraf et al. (2015).

TABLE 7. Effects of different sources of nitrogen fertilizers and spraying of some antioxidantson 100 -seed weight and seed yield during the two growing seasons.

\begin{tabular}{lcccc}
\hline \multirow{2}{*}{ Treatment } & \multicolumn{2}{c}{$\mathbf{1 0 0}$ - seed weight (g) } & \multicolumn{2}{c}{ Seed yield (kg/fad) } \\
& $\mathbf{2 0 1 4}$ & $\mathbf{2 0 1 5}$ & $\mathbf{2 0 1 4}$ & $\mathbf{2 0 1 5}$ \\
\hline Nitrogen fertilizers sources & & \\
\hline Urea & $6.58 \mathrm{c}$ & $6.72 \mathrm{c}$ & $1489.48 \mathrm{c}$ & $1512.68 \mathrm{c}$ \\
Ammonium nitrate & $7.52 \mathrm{~b}$ & $7.65 \mathrm{~b}$ & $1573.96 \mathrm{~b}$ & $1595.93 \mathrm{~b}$ \\
Ammonium sulfate & $8.39 \mathrm{a}$ & $8.58 \mathrm{a}$ & $1609.32 \mathrm{a}$ & $1620.27 \mathrm{a}$ \\
F- test & $* *$ & $* *$ & $*$ & $* *$ \\
LSD & 0.106 & 0.067 & 32.75 & 13.84 \\
\hline & Antioxidants concentrations & & $1521.36 \mathrm{e}$ \\
Control (untreated plants) & $7.19 \mathrm{e}$ & $7.32 \mathrm{~d}$ & $1506.12 \mathrm{e}$ & $1563.69 \mathrm{c}$ \\
Ascorbic at $150 \mathrm{mg} \mathrm{L}^{-1}$ & $7.47 \mathrm{c}$ & $7.62 \mathrm{c}$ & $1551.93 \mathrm{c}$ & $1638.61 \mathrm{a}$ \\
Ascorbic acid at $300 \mathrm{mg} \mathrm{L}^{-1}$ & $7.80 \mathrm{a}$ & $7.92 \mathrm{a}$ & $1617.93 \mathrm{a}$ & $1546.10 \mathrm{~d}$ \\
Citric acid at $250 \mathrm{mg} \mathrm{L}^{-1}$ & $7.37 \mathrm{~d}$ & $7.58 \mathrm{c}$ & $1519.29 \mathrm{~d}$ & $1611.67 \mathrm{~b}$ \\
Citric acid at $500 \mathrm{mg} \mathrm{L}^{-1}$ & $7.65 \mathrm{~b}$ & $7.81 \mathrm{~b}$ & $1592.65 \mathrm{~b}$ & $* *$ \\
F- test & $* *$ & $*$ & $*$ & 13.55 \\
LSD & 0.049 & 0.059 & 8.34 & \\
\hline
\end{tabular}

*** significant at $5 \%$ level of probability, respectively. Mean values designed by the same letter in each column are not significant according to Duncan's Multiple Range Test. 


\section{Effect on seed protein content}

The attained results in Table 8 showed that, different sources of nitrogen significantly affected seed protein percentage in the two growing seasons. Ammonium sulfate treatment gave the highest protein $\%$ as compared with the other nitrogen fertilizers sources. Increasing of crude protein content may be due to the fact that, nitrogen often plays an important role in the synthesis of protein. These results are fully in line with the findings of Amin (2011). Additionally, ammonium sulfate contain sulfur element which is an essential component of amino acids which are the building blocks of protein.

It is revealed from the data in Table 8 that applications of the two antioxidants caused significant promotion of seed protein content in the both seasons 2014 and 2015 with comparison to the untreated plants. The highest content of protein \% was recorded by foliar spraying with ascorbic acid at $300 \mathrm{mg} \mathrm{L}^{-1}$. In this concern, Talaat (2003) showed that foliar application of ascorbic acid has a positive effect on seed protein $\%$.
Regarding, Sadak et al. (2010) demonstrated that application of $\alpha$-tocopherol on sunflower plants led to the accumulation of total carbohydrates, stimulation of protein synthesis and delaying senescence of sunflower plants.

\section{Effect on seed oil content}

From the results in Table 8, data indicated that application of different forms of nitrogen significantly affected seed oil content during the two growing seasons. The highest percentage of oil \% was recorded with application of ammonium sulfate than other treatments. The increments in oil content due to ammonium sulfate application may be attributed to its promotive role in the formation of amino acids methionine $(21 \% \mathrm{~S})$ and cysteine $(27 \% \mathrm{~S})$; synthesis of proteins and oil content ofseeds (Jamal et al., 2010).Also, sulfuris an important element for oil crops which a constituent of acetyl Co-A, is converted into maloyl Co-A in fatty acid synthesis and for this conversion an enzyme, thiokinase is involved (Rasool et al., 2013).

TABLE 8. Effects of different sources of nitrogen fertilizers and spraying of some antioxidants seed protein and seed oil \% during the two growing seasons.

\begin{tabular}{|c|c|c|c|c|}
\hline \multirow{2}{*}{ Treatment } & \multicolumn{2}{|c|}{ Seed protein \% } & \multicolumn{2}{|c|}{ Seed oil \% } \\
\hline & 2014 & 2015 & 2014 & 2015 \\
\hline \multicolumn{5}{|c|}{ Nitrogen fertilizers sources } \\
\hline Urea & $15.33 \mathrm{c}$ & $15.63 \mathrm{c}$ & $43.81 \mathrm{c}$ & $44.16 \mathrm{c}$ \\
\hline Ammonium nitrate & $15.77 \mathrm{~b}$ & $15.95 \mathrm{~b}$ & $44.75 \mathrm{~b}$ & $45.04 \mathrm{~b}$ \\
\hline Ammonium sulfate & $15.97 \mathrm{a}$ & $16.15 \mathrm{a}$ & $45.60 \mathrm{a}$ & $45.71 \mathrm{a}$ \\
\hline $\mathrm{F}$-test & $* *$ & $* *$ & $* *$ & $* *$ \\
\hline LSD & 0.064 & 0.120 & 0.402 & 0.422 \\
\hline \multicolumn{5}{|c|}{ Antioxidants concentrations } \\
\hline Control (untreated plants) & $14.66 \mathrm{~d}$ & $14.82 \mathrm{~d}$ & $43.11 \mathrm{c}$ & $43.48 \mathrm{~d}$ \\
\hline Ascorbic at $150 \mathrm{mg} \mathrm{L}^{-1}$ & $15.51 \mathrm{c}$ & $15.76 \mathrm{c}$ & $44.65 \mathrm{~b}$ & $44.61 \mathrm{c}$ \\
\hline Ascorbic acid at $300 \mathrm{mg} \mathrm{L}^{-1}$ & $16.51 \mathrm{a}$ & $16.77 \mathrm{a}$ & $46.06 \mathrm{a}$ & $46.57 \mathrm{a}$ \\
\hline Citric acid at $250 \mathrm{mg} \mathrm{L}^{-1}$ & $15.49 \mathrm{c}$ & $15.66 \mathrm{c}$ & $44.32 \mathrm{~b}$ & $44.45 \mathrm{c}$ \\
\hline Citric acid at $500 \mathrm{mg} \mathrm{L}^{-1}$ & $16.29 \mathrm{~b}$ & $16.55 \mathrm{~b}$ & $45.47 \mathrm{a}$ & $45.73 \mathrm{~b}$ \\
\hline $\mathrm{F}$-test & $* *$ & $* *$ & $* *$ & $* *$ \\
\hline LSD & 0.082 & 0.190 & 0.709 & 0.414 \\
\hline
\end{tabular}


Regarding, the antioxidant, data in Table 8 indicated that spraying sunflower plants with $300 \mathrm{mg} \mathrm{L}^{-1}$ of ascorbic acid caused significant increment in oil content in comparison to the control (untreated plants) during the two growing seasons. The oil percentage in the first season was $(46.06 \%)$ and in the second season was $(46.57 \%)$ for that treatment. In this finding, our results are in good agreement with those obtained by Gamal El Din (2005) who reported that ascorbic acid significantly increased oil percentage of sunflower seeds. The increase in oil $\%$ with vitamin treatments might be attributed to the acceleration of the biosynthetic pathway of linolenic acid (Joshi et al., 1998).

\section{Conclusions}

The findings clearly showed that, form of nitrogen is an important tool for increasing seed yield and seed quality. Ammonium sulfate recorded to improve yield and its components - Additionally, based on the results discussed it could be concluded that foliar spraying of antioxidants have an enhancement role in growth, yield and seed quality of sunflower plant. So,we can recommended to use nitrogen in the form of ammonium sulfate with foliar spraying of $300 \mathrm{mg}$ $\mathrm{L}^{-1}$ ascorbic acid.

\section{References}

Abd El-Al., F.S. (2009) Effect of urea and some organic acids on plant growth, fruit yield and its quality of sweet pepper (Capsicum annum). Res. J. Agric. and Biol. Sci. 5 (4), 372-379.

Abdel Gader, E.O. (2007) Effect of different nitrogen sources on growth and yield of maize (Zea mays L.). Unpublished M.Sc. Thesis, OmDurman Islamic University, Fac. of Agric., Sudan.

Abd EI- Hakim, W. M. (2006) Effect of some antioxidant treatments on chemical constituents, antinutritional factors and yield of some vegetable legumes. Ph.D. Thesis, Fac. of Agric., Minia Univ., Egypt.

Abd El- Naeem, G. F. and Abd El- Hakim, W.M. (2009) Evaluation of yield, chemical constituents and antioxidative activities of phenolic compounds in some vegetable legume treated with some antioxidants. Minia J. Agric. Res. Develop. 29(3),459-495.

Al- Qubaie, A. I. (2012) Response of sunflowers cultivar Giza- 102 (Helianthus annuus, L) plants to spraying some antioxidants. Nature and Science, 10 (11).
Amin, M.E.H. (2011) Effect of different nitrogen sources on growth, yield and quality of fodder maize (Zea mays L.). J. Saudi Soc. Agric. Sci. 10, $17-23$.

A.O.A.C. (1995) "Official Methods of Analysis"1 $6^{\text {th }} \mathrm{ed}$ A.O.A.C Benjamin Ranklin Station, Washington, D.C, U.S.A.pp 490-510.

Athar, H.R., Khan, A. and Ashraf, M. (2008) Exogenously applied ascorbic acid alleviates saltinduced oxidative stress in wheat. Environ. Exp. Bot. 63, 224-231.

Bakry, A.B., Abdelraouf, R.E., Ahmed, M.A. and ElKaramany, M.F. (2012) Effect of drought stress and ascorbic acid foliar application on productivity and irrigation water use efficiency of wheat under newly reclaimed sandy soil. J. Appl. Sci. Res. 8 (8), $4552-4558$.

Barth, C., De Tullio, M. and Conklin, P.L. (2006) The role of ascorbic acid in the control of flowering time and the onset of senescence. J. Exp. Bot.57, $1657-1665$.

Davey, M.W., Van Monatgu, Sanmatin M., Kanellis, A., Smirnoff, N., Benzie, I.J.J., Strain, J.J. and Favell, D. Fletcher (2000) J. Plant L-Ascorbic Acid: chemistry, function, metabolism, bioavailability and effects of processing. J.Sci. Food Agric. 80, $825-860$.

De Tullio, M.C. and Arrigoni, O. (2003) The ascorbic acid system in seeds: to protect and to serve. Seed Sci. Res.13, 249-260.

El-Kobisy, D.S., Kady, K.A., Hedani, R.A. and Agamy, R.A. (2005) Response of pea plant (Pisum sativum L.) to treatment with ascorbic acid. Egypt. J. Appl. Sci. 20, 3650-.

Elmar, S. (2001) The importance of ammonium sulphate nitrate (ASN) as highly efficient sulfate Sudanese crops (FertivaCmbH, Germany). Fertilizer Workshop on May 26, Khartoum, Sudan.

FAS-USDA (2017) Foreign Agricultural Service/ United States Department of Agricultural . May 2017.

Gamal El-Din, K.M. (2005) Physiological studies on the effect of some vitamins on growth and oil content in sunflower plant. Egypt. J. Appl. Sci. 20, 560-571.

Hassanein, R.A., Bassuony, F.M., Barakat, D.M. and Khalil, R.R. (2009) Physiological effects of nicotinamide and ascorbic acid on zea mays plant 
grown under salinity stress. 1- Changes in growth, some relevant metabolic activities and oxidative defense systems. Res. J. Agric. and Biol. Sci. 5 (1), $72-81$.

Hanna, F.R., Abdo, F.A. and Anton, N.A. (2001) Response of wheat plant to foliar application with ascorbic acid, copper and boron. J. Agric. Sci. Mansoura Univ. 26 (10), 5971-5983.

Helsper, J.P., Kagan, I., Maynard, J.M. and Loewus, F.A. (1982) L. Ascorbic acid biosynthesis in Ochromonas danica. Plant Physiol. 69, 458-468.

Hussein, M.M., Abd El-Rheem, Kh. M., Khaled, S.M. and Youssef, R.A. (2011) Growth and nutrients status of wheat as affected by ascorbic acid and water salinity. Nature and Science, 9 (10), 64-69.

Hymowitz, T. F., Collins, P. and Walker, W. M.(1972) Relationship between the content of oil, protein and sugar in soybean seed. Agronomy J. 64, $613-616$.

Irfan, A., Basra, S.M.A., Mahammed, F. and Nawaz, A. (2006) Alleviation of salinity stress in spring wheat by hormonal priming with ABA, salisylic acid and ascorbic acid. International J. Agric. Biology, 8 (1), 23- 28.

Jamal, A., Yong-Sun, M. and Malik Zainul, A. (2010) Sulphur-ageneral overview and interaction with nitrogen. Australian J. Crop Science, 4 (7), 523529.

Johnason, R.E. (1967) Comparison of method for estimating cotton leaf area. Agron. J. 59, 493-494.

Joshi, N.L., Mali, P.C. and Anurag, S. (1998) Effect of nitrogen and sulfur application on yield and fatty acid composition of mustard (Brassica junceaL.) oil. J. Agron. Crop Sci. 180, 59-63.

Leon, A.J., Andrade, F. and Lee, M. (2003) Genetic analysis of seed-oil concentrations across generations and environments in sunflower (Helianthus annuusL.). Crop Sci. 43, 135-140.

Lopez, P.M., Trapani, N. and Sadras, V. (2000) Genetic improvement of sunflower in Argentina between 1930 and 1995. III. Dry matter partitioning and achene composition. Field Crop Res. 67, 215-221.

Malik, S.M., Majid, R.R. and Cheema, N.A.A. (1996) Determining a suitable rate and source of nitrogen for realization the higher economic returnsfrom autumn sown sunflower. International J. Agric. Biology, 4, 347-349.

Monotti, M. (2004) Growing non-food sunflower in dry land conditions.Ital. J. Agron. 8, 3-8.
Moran, R. (1982) Formula determination of chlorophylls pigments extracted with N-N dimethyl-frmamide. Plant Physiol. 69, 1376 - 1381.

Nasim, W., Ahmad, A., Bano, A., Olatinwo, R., Usman, M., Khaliq, T., Wajid, A., Mohkum, H., Hammad Mubeen, M. and Hussain, M. (2012) Effect of nitrogen on yield and oil quality of sunflower (Helianthus annuus L.)hybrids under sub humid conditions of Pakistan. American Journal of Plant Sciences, 3, 243-251.

Nassar, R.M.A. (2013) Response of mungbean plant (Vigna radiate (L.) Wilczek) to foliar spray with ascorbic acid. J. Appl. Sci. Res. 9 (4), 2731-2742.

Noctor, G., Arisi, A., Jouanin, L., Kunert, K. J., Rennenberg, H. and Foyer, C. H. (1998) Glutathione: biosynthesis, metabolism and relationship to stress tolerance explored in transformed plants. J. Exp. Bot. 49, 623-647.

Nofal, M.A., Rabie, M.H. Khalid, K.M. and Mohamed, A.F. (1990) Growth and some micro-nutrients content of letice plants as applied by seed soaking and foliar spray of ascorbic and citric acid. Proc. of Soil Fertility and Foliar Fertilization. Conf., Giza, Egypt, , Paper No. 3, pp.14-15 Jan.

Piper, C.S. (1950) "Soil and Plant Analysis". Interscience Pumlisher. Inc. New York, USA.

Patra, P., Pati, B.K., Ghosh, G.K., Mura, S.S. and Saha, A. (2013) Effect of biofertilizers and sulphur on growth, yield, and oil content of hybrid sunflower (Helianthus annuus. L) in a typical lateritic Soil.Open Access Scientific Reports. 2 (1).

Rasool, Faisul-ur, Hasan, Badrul., Aalum, I. and Ganie, S.A. (2013) Effect of nitrogen, sulphur and farmyard manure on growth dynamics and yield of sunflower (Helianthus annuus L.) under temperate conditions. Scientific Research and Essays, 8 (43), 2144-2147

Sadak, M. Sh., Rady, M.M., Badr, N.M. and Gaballah, M.S. (2010) Increasing sunflower salt tolerance using nicotinamide and $\alpha$-tocopherol. Int. J. Acad. Res. 2, 263-270.

Smirnoff, N. (2000) Ascorbic acid: metabolism and functions of a multi-facetted molecule. Current Opinion in Plant Biol. 3, 229-235.

Snedecor, G.W. and Cochran, W.G.(1982) "Statistical Methods" $6^{\text {th }}$ ed. Iowa State College Press. Ams. Iowa, U.S.A.

Talaat, N.B. (2003) Physiological studies on the effect of salinity, ascorbic acid and putrescine of sweet pepper plant. Ph.D. Thesis, Fac. Agric.Cairo Univ., Egypt. 
Tarraf, S.A.Y., El-Harbby, B.M., Ahmed, M.A. and Shalaby, M.A. (2015). Alleviation of cold stress effects on alfaffa (Medicago sativa L.) by stigmasterol and ascorbic acid under Tabouk Governorate, Saudi Arabia Kingdom Condition. Middle East J. Appl. Sci. 5 (3), 726-733.

Toosi,A.F.andAzizi, M.(2014)Effectofdifferentsources of nitrogen fertilizer on yield \& yield components of sunflower (Helianthus annus L.). Scientific Papers. Series A. Agronomy, Vol. LVII, 2014.

Youssef, E.A., Ahmed, M.A., Badr, N.M., Shafaby, M.A.F. and Gamal El-Din, K.M. (2015) Alleviation of drought effect on sunflower (Helianthus annus L.) c.v Sakha-53 cultivar by foliar spraying with antioxidant. Middle East J. Agric. Res. 4 (4),794801

Zewail, Y.M.R. (2007) Improvement of wheat productivity by using some biofertilizers and antioxidants. M.Sc. Thesis, Fac. Agric. Moshtohor, Banha Univ., Egypt.

Zubillaga, M.M., Aristi, J.P. and Lavado, R.S. (2002) Effect of phosphorus and nitrogen fertilization on sunflower(Helianthus annus L.) nitrogen uptake and Yield. J. Agronomy \& Crop Science, 188, 267-274.

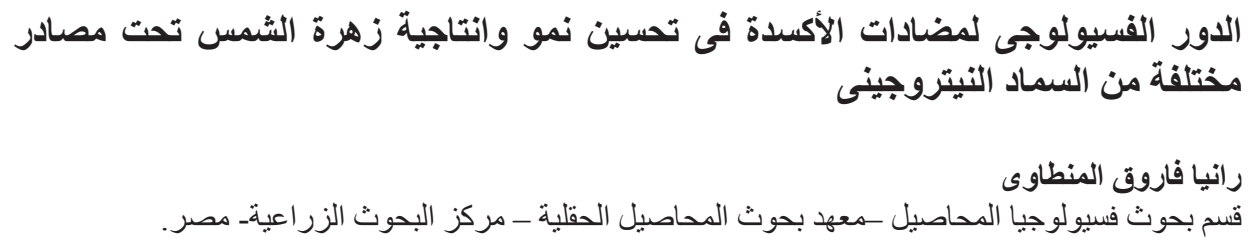

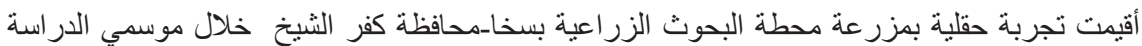

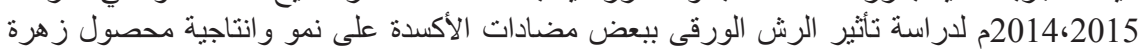

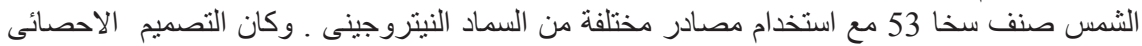

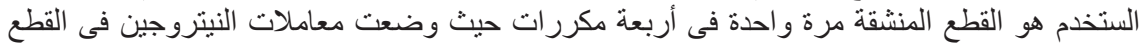

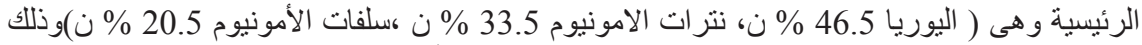

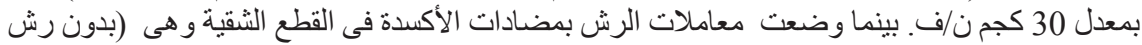

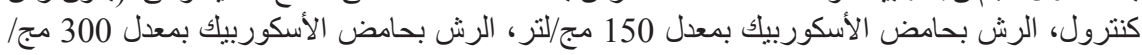

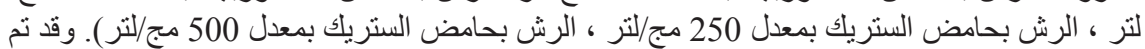

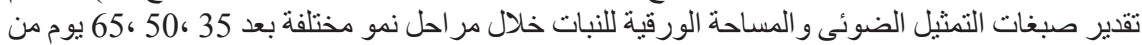

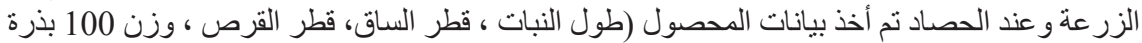

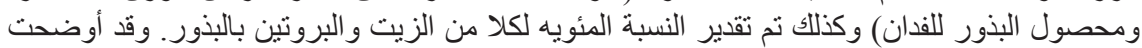

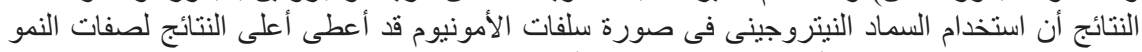

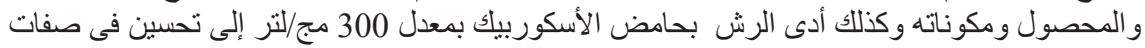

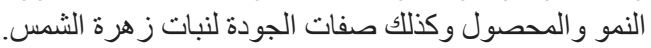

